\title{
Результати роботи \\ ДУ «Нститут ендокринології та обміну речовин \\ ім. В.П. Комісаренка НАMH України» за 2018 рік
}

\section{М.Д. Тронько, О.І. Ковзун, Н.В. Сологуб, I.В. Гончар, І.П. Пастер}

ДУ «Інститут ендокринології та обміну речовин ім. В.П. Комісаренка НАМН України»

Інститут ендокринології та обміну речовин ім. В.П. Комісаренка створено згідно з постановою Кабінету Міністрів України № 1244 від 19.12.1964 р. (наказ МОЗ України № 40 від 18.01.1965 р.). Відповідно до постанови Кабінету Міністрів України № 211 від 22.03.1993 р. Інститут передано в підпорядкування Академії медичних наук України. Відповідно до постанови Кабінету Міністрів України № 732 від 13.07.2011 р. «Про внесення змін до постанови Кабінету Міністрів України від 18 жовтня 1999 року № 1913 «Про затвердження Статуту Академії медичних наук України» внесено такі зміни до найменування установи: Державна установа «Інститут ендокринології та обміну речовин ім. В.П. Комісаренка Національної академії медичних наук України» (постанова Президії Національної академії медичних наук України № 19/8 від 06.10.2011р.).

На сьогодні Державна установа «Інститут ендокринології та обміну речовин ім. В.П. Ко-

* Адреса для листування (Correspondence): ДУ «Інститут ендокринології та обміну речовин ім. В.П. Комісаренка НАМН України», вул. Вишгородська, 69, м. Київ, 04114, Україна. E-mail: zdovado@ukr.net

○ М.Д. Тронько, О.І. Ковзун, Н.В. Сологуб, І.В. Гончар, І.П. Пастер місаренка НАМН України» (далі - Інститут) є науковим, консультативним і лікувальним закладом, що надає допомогу дорослим і дітям із захворюваннями щитоподібної залози, цукровим діабетом та іншою ендокринною патологією.

Також Інститут є провідною в Україні науково-дослідною базою для підготовки аспірантів, клінічних ординаторів, захисту докторських і кандидатських дисертацій із фаху «ендокринологія», підготовки фахівців на курсах стажування та інформації.

Після аварії на Чорнобильській АЕС Інститут є базовим закладом в Україні з питань дослідження їі впливу на стан щитоподібної залози (ЩЗ). В Інституті створено клініко-морфологічний реєстр хворих на рак ЩЗ віком від 0 до 18 років на час аварії на ЧАЕС. Вивчаються молекулярно-біологічні, генетичні, морфологічні та імунологічні аспекти тиреоїдного раку. Встановлено залежність захворюваності на рак ЩЗ від дози опромінення. Розроблено сучасні методи ультразвукової діагностики захворювань ЩЗ і пункційної біопсії їі ново- 
утворень, удосконалено та впроваджено нові підходи до хірургічного лікування хворих на рак ЩЗ і поопераційного лікування таких хворих радіоактивним йодом і тироксином. Впровадження наукових і практичних розробок, виконаних в Інституті, дозволило мінімізувати негативні наслідки радіаційного впливу на ЩЗ дітей і підлітків в Україні.

Характерною рисою роботи Інституту $\epsilon$ широке міжнародне співробітництво з питань, пов'язаних із вивченням впливу Чорнобильської катастрофи на структуру та функцію Щ3, з установами США (Національний інститут раку, Колумбійський і Каліфорнійський університети), Великої Британії (Імперіалколедж, Лондон), Німеччини (Науково-дослідний центр екології та здоров'я, Нойєрберг; Університет Вюрсбурга; Університет ім. Гумбольдта, Берлін), Японії (Медичний університет, Нагасакі; Фонд «Сасакава»), Італії (Навчальний університет, Неаполь; Університет Мілана; Університет Пізи), Франції (Університет Реймса), Канади (Університет Торонто), Бельгії (Вільний Брюссельський університет). Проекти виконуються в рамках ВООЗ, Комісії Європейського співтовариства, дитячого фонду ООН ЮНІСЕФ,

За підтримки Європейського союзу, Національного інституту раку (США), Фонду «Сасакава» (Японія) в Інституті виконується проект СП5-Свроатом № 211712 «Чорнобильський банк тканин - координовані міжнародні дослідження радіоіндукованого тиреоїдного раку», який є продовженням попередніх міжнародних наукових проектів щодо створення банку тканин, екстрактів ДНК і РНК із пухлин ЩЗ у хворих, які були дітьми та підлітками на момент аварії на ЧАЕС.

У співпраці з лабораторіями тиреоїдного канцерогенезу Кембриджського університету (Велика Британія), молекулярної біології Уолтер Рід шпиталю (США), молекулярної патології Уельського університету та молекулярної патології Імперіал-коледжу Лондона (Велика Британія) проведено молекулярнобіологічні дослідження з метою пошуку нових маркерів раку ЩЗ.

Із 1998 р. в Інституті спільно з Національним інститутом раку (США) виконується Українсько-Американський тиреоїдний проект «Науковий проект дослідження раку та інших захворювань щитоподібної залози в Україні в результаті аварії на Чорнобильській AEC», основною метою якого є здійснення широкомасштабних епідеміологічних та клініко-морфологічних досліджень для виявлення різних форм патології ЩЗ в осіб, опромінених радіоактивним йодом унаслідок аваpiї на ЧАЕС. Із 2014 р. у рамках тиреоїдного проекту розпочато комплексний повногеномний аналіз тиреоїдного радіоіндукованого папілярного раку з метою встановлення механізмів радіаційного канцерогенезу та чутливості геному радіаційного впливу.

Протягом багатьох років провідним напрямом наукової діяльності Інституту є вивчення етіології, патогенезу, клініки цукрового діабету (ЦД), удосконалення діагностики, лікування та профілактики цього захворювання. Згідно 3 Розпорядженням НАМН України № 5 від 03.09.2009 р., Інститут було визначено головною установою щодо організаційнометодичного та наукового керівництва реалізацією завдань і заходів Державної програми «Цукровий діабет».

У ході виконання програми було створено умови для значного поліпшення допомоги хворим на Цд, вчасного виявлення хвороби та iii ускладнень, поліпшення якості життя хворих. До створеного Інститутом за допомогою ендокринологів усієї країни реєстру входять майже всі дорослі хворі, які отримують інсулін в Україні, та значна кількість пацієнтів, які отримують пероральне лікування. Загальна кількість хворих наразі становить близько 500 тис. Територіальні бази даних - реєстри хворих на ЦД - визнані Свропейським товариством дослідників ЦД (EASD) новим важливим інструментом у вивченні епідеміології захворювання.

Одним з основних досягнень програми «Цукровий діабет» стало вирішення питання базового забезпечення інсуліном хворих на ЦД за рахунок вітчизняного виробника. В Україні налагоджено випуск інсулінів на заводах «Індар» $\mathrm{i}$ «Фармак», якість яких відповідає як європейській, так і американській фармакопеям.

Триває розвиток служби «Діабетична стопа». Створено мережу кабінетів діагностики діабетичної полінейропатії, яка є головним чинником розвитку трофічних уражень нижніх кінцівок, де всі хворі на ЦД проходили 
скринінгове обстеження на предмет виявлення чинників ризику синдрому діабетичної стопи та вчасного лікування цього ускладнення. Наразі в Україні за єдиними європейськими стандартами працює понад 30 кабінетів діагностики нейропатії. Крім того, за сприяння Інституту започатковано роботу 3 формування мобільних кабінетів діабетичної стопи та діагностики діабетичної полінейропатії, а в майбутньому - створення Центрів судинної хірургії.

Протягом багатьох років Інститут вивчає проблему йодного дефіциту в Україні. Інститут із цього питання співпрацює з Центром діагностики та профілактики йододефіцитних захворювань (Атланта, США). Україна входить до програми ЮНІСЕФ і ВООЗ із контролю йодної недостатності. Епідеміологічні дослідження, виконані в Інституті, показали, що населення всіх областей України потерпає від нестачі йоду. Запропоновано шляхи подолання йодного дефіциту в Україні, одним з яких є підготовлений проект Закону України «Про запобігання станам і захворюванням, спричиненим йодною недостатністю», який передбачає постійний моніторинг йодної забезпеченості та захворюваності населення й впровадження масової йодної профілактики через вживання йодованої солі. Розроблену Інститутом Державну програму «Профілактика йодної недостатності в населення України» направлено до Президії НАМН України та МОЗ України для узгодження та затвердження.

22.11.2018 р. Інститут отримав новий Сертифікат на систему управління якістю стосовно надання послуг із діяльності лікарняних закладів, послуг у сфері загальної та спеціалізованої лікарської практики, послуг у сфері охорони здоров'я, із досліджень й експериментальних розробок у сфері біотехнологій, інших природничих і технічних наук, послуг у сфері вищої освіти, що відповідає вимогам ДСТУ ISO 9001:2015 «Система управління якістю. Вимоги» (ISO 9001:2015, IDT). Сертифікат дійсний до 21.11.2021 р.

Інститут виконує широке коло фундаментальних і прикладних науково-дослідних робіт, результати яких високо цінуються науковими співробітниками та практикуючими лікарями.

\section{ФУНДАМЕНТАЛЬНІ ДОСЛІДЖЕННЯ У СФЕРІ ТЕОРЕТИЧНОї ТА КЛІНІЧНОЇ МЕДИЦИНИ}

Протягом 2018 р. в Інституті виконували 3 науково-дослідні роботи, що фінансуються 3 бюджету НАМН України за КПКВ 6561040 «Фундаментальні дослідження у сфері теоретичної та клінічної медицини», із термінами виконання 2017-2019 рр.:

НДР «Визначення рівня проліферативних процесів, стану мітогенних сигнальних каскадів та експресії мікроРНК у клітинах щитоподібної залози та надниркових залоз» (науковий керівник: д.мед.н., професор, акад. НАМН України, член-кор. НАН України Тронько М.Д.)

Розширено концепцію мультифакторної регуляції адренокортикальної функції за участю різних систем сигнальної трансдукції в клітинах кори надниркових залоз (Н3).

Показано, що суттєва роль у трансдукції сигналу в адренокортикоцитах належить сигнальному каскаду протеїнкіназ, що активуються мітогенами, а саме позаклітинній сигнал-регульованій кіназі-1/2 (ERK 1/2), яка бере участь у перенесенні сигналів літію, та ядерними чинниками транскрипції c-jun i c-fos, експресія яких змінюється під дією ацильованих похідних етаноламіну (NAE).

3'ясовано участь протеїнкінази GSK-3 $\beta$ у реалізації дії іонів калію. Встановлено, що ця протеїнкіназа є важливим регулятором проліферативних процесів, апоптозу, диференціації, транспорту глюкози та інших біохімічних процесів.

НДР «Експериментальне вивчення віддалених нейроендокринних розладів, зумовлених пренатальною дією ендокринних дизрапторів $з$ антиандрогенною або естрогеноподібною активністю» (науковий керівник: д.мед.н., професор, акад. НАМН України, член-кор. НАН України Резніков О.Г.)

Продовжено дослідження патогенного впливу ендокринних дизрапторів 3 антиандрогенною та естрогеноподібною активністю (дибутилфталат, бісфенол А), які отримували вагітні тварини, на репродуктивні органи, гормональне забезпечення, нейроендокринну систему та поведінку чоловічого потомства першої генерації.

Виявлено передчасне згасання репродуктивної функції самців, морфологічні зміни 
нейроцитів медіально-преоптичного ядра гіпоталамуса, атрофія та дегенерація статевих залоз і передміхурової залози, посилена пероксидація ліпідів у сім'яниках і простаті внаслідок пренатального впливу низьких доз дибутилфталату. В експериментах на самцях доведено здатність інгібітору ароматази стероїдів летрозолу активувати статеву систему старіючих тварин завдяки зміні гормонального профілю.

Отримані дані можуть бути використаними для клінічного випробування летрозолу з метою лікування синдрому естрогенної домінанти й ожиріння в чоловіків.

НДР «Проспективне клініко-імунологічне дослідження стану дітей i підлітків, позитивних за наявністю діабет-асоційованих автоантитіл, у різні терміни після клінічного дебюту цукрового діабету 1-го типу» (науковий керівник: д.мед.н., професор Зак К.П.)

Тривало дослідження 3 визначення показників імунітету в дітей із підвищеними рівнями діабет-асоційованих автоантитіл (ДААт + дітей) 3 обтяженою спадковістю щодо ЦД 1-го типу (ЦД1). Створено Реєстр маркер-позитивних дітей із прогнозованим розвитком ЦД1, що нараховує 612 дітей віком від 7 до 15 років 3 обтяженою спадковістю (родичі першої лінії, які хворіють на ЦД1, - батьки, брати та сестри), в яких визначено титр діабет-асоційованих автоантитіл.

Уточнюються дані про частоту та динаміку титрів автоантитіл - GADA, IA-2A та IAA в дітей і підлітків на етапах еволюції ЦД1, зокрема стосовно дебюту ЦД1, що дає можливість визначати найбільш значущі маркери розвитку ЦД1 і формулу поєднаної наявності та значень одночасно підвищених титрів ДААт, а саме IA-2A+GADA як превалюючої комбінації для розвитку ЦД1.

Доведено, що розвитку ЦД1 у ДААт+ дітей передує підвищення рівня прозапальних цитокінів ІЛ-1 $\alpha$, ІЛ-6 і ЧНП $\alpha$, хемокіну ІЛ-8 і хемоатрактанту IЛ-16, що позитивно корелює 3 підвищеними титрами IA-2A i GADA $з$ одночасним зниженням концентрації IЛ-4 в периферичній крові.

Уперше показано, що ступінь зниження кількості CD3+, CD4+ і CD56+ клітин і концентрації ІЛ-4 на тлі підвищених рівнів IЛ-6, ІЛ-8, ЧНП $\alpha$ у крові ДААт+ дітей в передклі- нічний, латентний період розвитку ЦД1 є маркером швидкості розвитку й агресивності перебігу захворювання.

\section{ПРИКЛАДНІ ТА НАУКОВО-ТЕХНІЧНІ РОЗРОБКИ}

В Інституті 2018 року завершено виконання 7 науково-дослідних робіт, що фінансувалися з бюджету НАМН України за КПКВ 6561040 «Прикладні та науково-технічні розробки», із термінами виконання 2016-2018 рр.:

НДР «Розробка персоніфікованих підходів у діагностиці та фармакотерапії цукрового діабету 2-го типу» (науковий керівник: д.мед.н., професор Корпачев В.В.)

Розроблено персоніфіковані підходи до діагностики та корекції гормонально-метаболічних порушень у хворих на ЦД 2-го типу (ЦД2) залежно від конституційних особливостей. Показано, що застосований у комплексному лікуванні хворих на ЦД2 з адипозо-вісцеральним фенотипом препарат із групи інгібіторів натрій-глюкозного котранспортера глюкози 2-го типу (SGLT-2) - дапагліфлозин проявляє адитивні ефекти з бігуанідом метформіном, що забезпечує ефективнішу корекцію показників вуглеводного, ліпідного та пуринового обміну порівняно з монотерапією метформіном. Зафіксовано зниження урикемії, що зумовлено значним збільшенням екскреції уратів за рахунок зростання кліренсу сечової кислоти та зменшення реабсорбції її в ниркових канальцях.

Виявлено позитивні зміни показників ліпідного спектра крові хворих на ЦД2: зменшення рівня тригліцеридів і холестерину ліпопротеїнів низької щільності, підвищення рівня тригліцеридів ліпідної фракції ХС ЛПВЩ. Застосування препарату позитивно впливає на показники вуглеводного обміну. Особливістю хворих $з$ аліментарно-кінетичним фенотипом було зниження маси тіла за рахунок зменшення кількості підшкірного жиру, тоді як у групі хворих на ЦД2 з адипозо-вісцеральним фенотипом спостерігали зниження абдомінального ожиріння без суттєвої зміни IMT.

Аргументовано доцільність проведення моніторингу жирнокислотного складу окремих ліпідних фракцій і показників ліпідного спектра сироватки крові у хворих на ЦД2 з ізольованими формами дисліпідемії з метою визначення засобів патогенетичної фармакотерапії 
для корекції встановлених ліпідних порушень та оцінки ефективності лікування. Запропоновано рекомендації щодо діагностики типів ізольованої дисліпідемії у хворих на ЦД2 для визначення провідних механізмів порушення ліпідного обміну.

Досліджено особливості порушення кісткового ремоделювання за вмістом остеокальцину в крові та зміни мінеральної щільності критичних зон скелета на тлі ЦД2 залежно від конституційних та антропометричних фенотипів. Отримані дані свідчать про взаємозв’язок між зменшенням вмісту остеокальцину в крові та наявністю ЦД2 навіть у пацієнтів із нормальною масою тіла. Із підвищенням індексу інсулінорезистентності, поряд зі зростанням маси тіла та збільшенням обводу талії, знижуються показники остеокальцину та, як наслідок, уповільнюються процеси остеосинтезу. Тобто, формування метаболічних фенотипів, характерних для ЦД2 з переважанням андроїдного ожиріння, є однією 3 патогенетичних ланок погіршення стану кісткової тканини внаслідок уповільнення остеосинтезу.

НДР «Вивчити основні шляхи прогресування та взаємообтяження судинної патології у хворих на цукровий діабет 1-го та 2-го типів із метою вдосконалення сучасних методів профілактики та лікування» (науковий керівник: д.мед.н., с.н.с. Соколова Л.К.)

Показано, що показники захворюваності населення на ЦД щорічно зростають, і наразі поширеність ЦД в Україні становить 2,9\%. Частота ускладнень як серед хворих із Цд1, так і з ЦД2 впродовж 2016-2017 років суттєво не змінилась і є низькою.

Виявлені під час гіпоглікемії за результатами холтерівського моніторингу електрофізіологічні зміни свідчать про погіршення кровообігу міокарда та вказують на збільшення ризику серцево-судинних ускладнень у хворих на ЦД на тлі гіпоглікемії.

Поширеність анемії серед хворих на ЦД1 і ЦД2 становить 66\%. У більшості хворих (45,5\%) з анемією ХХН не виявлено, у 9\% випадків діагностовано діабетичну нефропатію III ст., у 18\% - IV ст., у 27,5\% - ХНН. Встановлено збільшення кількості хворих з анемією зі збільшенням протеїнурії, рівня креатиніну та зменшенням ШКФ. У пацієнтів з анемією відзначався високий рівень NT-proBNP і креатиніну, погана стерпність фізичних навантажень, більша потреба в діуретиках, підвищений вміст протизапальних цитокінів (ЦК) i C-реактивного білка. Найвищий рівень NT-proBNP спостерігали в крові пацієнтів із ЦД і тяжкою анемією. У пацієнтів, які мали анемію легкого ступеня, кількість NTproBNP була нижчою майже вдвічі. У пацієнтів із ЦД2, які приймали дапагліфлозин, рівні NT-proBNP було додатково знижено на $42 \%$ порівняно з вихідними.

Висока тривожність у більшості госпіталізованих хворих на ЦД підкреслює необхідність враховувати цю патологію в лікуванні пацієнтів. Доведено, що терапія за допомогою композиції рослинних препаратів звіробою та валеріани позитивно впливає на клінічну симптоматику тривожно-депресивного синдрому у хворих на ЦД, зокрема на стан ситуативної та особистісної тривожності.

НДР «Дослідження антропометричних, біохімічних i генетичних факторів ризику розвитку порушеної регуляції рівнів глюкози та цукрового діабету 2-го типу в Україні з метою його профілактики» (наукові керівники: д.мед.н., професор Кравченко В.І., д.мед.н., доцент Халангот М.Д.)

У популяційному дослідженні вперше продемонстровано, що збільшення рівнів глюкози в плазмі крові після стандартного навантаження (але не глікемії натще) підвищує шанси виявлення коротких теломер лейкоцитів (LTL). Також встановлено, що в осіб із метаболічним синдромом наявно скорочення LTL, і на цей феномен впливає не лише вік, а й порушення толерантності до глюкози.

Дослідження створеної епідеміологічної когорти (334 особи) встановило зв’язок між умовами харчування в дитинстві та ризиком виявлення ЦД у похилому віці, надало можливість визначити реальну поширеність ЦД2 серед дорослих (близько 8\%) і встановити антропометричні особливості відмінних за патогенезом типів гіперглікемії. Створена когорта під назвою «Risk markers of impaired glucose regulation categories and screen-detected type 2 diabetes in rural Ukraine» увійшла до бази даних триваючих епідеміологічних досліджень в Європі INTERConnect.

НДР «Наукове обгрунтування та вдосконалення діагностики та лікування ендо- 
кринопатій у дитячому та підлітковому віці на підставі вивчення пріоритетних етіопатогенетичних факторів» (науковий керівник: д.мед.н., професор Большова О.В.)

Уперше в Україні здійснено комплексне дослідження фізичного та гормонального стану дітей і підлітків, хворих на синдром біологічно неактивного гормону росту (СБНГР). Досліджено частоту СБНГР серед хворих на низькорослість і визначено клінічні прояви та фенотип таких дітей. Розроблено та патогенетично обгрунтовано алгоритми діагностики СБНГР (тип Коварськи) та інших форм низькорослості зі збереженою соматотропною функцією гіпофіза. Доведено, що для генетичного підтвердження СБНГР інформативнішою $є$ методика секвенування гена гормону росту (ГР). Розроблено алгоритми діагностики та методологічні підходи до патогенетичної замісної терапії залежно від хронологічного та біологічного віку пацієнтів з урахуванням їх прогнозованого зросту.

Оцінено значення серологічних маркерів целіакії (Ц) у діагностиці коморбідності в дітей, хворих на ЦД1. Діти із ЦД1 становлять групу ризику виникнення Ц. У таких дітей Ц трапляється в 10 разів частіше, ніж у загальній популяції, та є коморбідністю на підставі автоімунних механізмів із загальним молекулярно-генетичним поліморфізмом. Скринінг на Ц виконували в дітей із уперше діагностованим ЦД1 і в подальшому кожні 2 роки. Діагноз Ц верифіковано за результатами біопсії постбульбарного відділу дванадцятипалої кишки. Проводили HLA-типування та серологічні тести: визначення антитіл до тканинної трансглютамінази (ТкТГ) IgA та IgG, ендомізійних (EMA) антитіл IgA i IgG і до дезамінованих пептидів гліадину (ДПГ) IgG.

HLA-типування DQ2 і DQ8 є необхідним, але недостатнім для діагностики Ц. Головна мета HLA-типування DQ2 і DQ8 - виключення діагнозу Ц. Якщо результат HLA-DQ2 негативний, імовірність розвитку Ц є дуже низькою (негативне прогностичне значення). Скринінг на Ц доцільно виконувати в усіх дітей з уперше діагностованим ЦД1, у разі негативного результату - наступними роками 3 такими інтервалами: перші 4 роки - щорічно, у подальшому - кожні 2 роки протягом 10 років і більше.
НДР «Вивчити стан репродуктивної функції в чоловіків, хворих на рак щитоподібної залози, після комбінованого радикального лікування та обгрунтувати методи корекції виявлених порушень» (науковий керівник: д.мед.н., професор Лучицький Є.В.)

У чоловіків, хворих на рак щитоподібної залози (РЩ3), обстежених після оперативного лікування та двох і більше курсів радіойодтерапії (РЙТ), виявлено вірогідне підвищення концентрації фолітропіну (ФСГ) у крові через 4-6 місяців і 8-12 місяців, причому найвищий рівень ФСГ виявлено через 8-12 місяців після проведеного курсу лікування. Середній рівень гормону в крові пацієнтів, які отримали декілька курсів РЙТ, був вірогідно вищим через 8-12 місяців після останнього курсу порівняно $з$ показником пацієнтів, які отримали один курс РЙТ. Середні концентрації лютеїнізуючого гормону, загального та вільного тестостерону та пролактину у хворих на РЩЗ чоловіків після двох і більше курсів РЙТ вірогідно не відрізнялися від показників контрольної групи. У таких хворих після декількох курсів РЙТ відбулося вірогідне підвищення відсотка дефрагментації ДНК сперматозоїдів у найближчі та віддалені терміни після лікування. Дослідження морфофункціональних показників сперми в обстежених виявили зниження кількості сперматозоїдів, відсотка фракції активно рухливих сперматозоїдів і підвищення кількості лейкоцитів в еякуляті.

НДР «Характеристика оксифільноклітинних змін у папілярних карциномах щитоподібної залози у взаємозв'язку з часом, що минув після аварії на ЧАЕС, і результатами післяопераційного спостереження хворих» (наукові керівники: д.мед.н., професор, акад. НАМН України, член-кор. НАН України Тронько М.Д., д.б.н., професор Богданова T.I.)

Встановлено, що протягом 2015-2017 pp. зберігалися зростаючі часові тренди показників захворюваності на РЩЗ серед осіб, які були дітьми та підлітками на момент аварії на ЧAEC, а також різниця між показниками захворюваності в 6 найбільш забруднених йодом-131 регіонах і решті регіонів України, що свідчить про наявність додаткової компоненти радіогенної захворюваності в Україні впродовж 31 року після аварії на ЧАЕС. 
Зміни гістопатологічних характеристик зі збільшенням віку хворих (вікові тренди) доводять, що фенотип як «радіогенних», так і «спорадичних» папілярних тиреоїдних карцином (ПТК) стає менш інвазійним у старшому віці, причому оксифільноклітинні зміни більш притаманні «спорадичним» ПТК. У серії потенційно радіогенних карцином, видалених у хворих віком від 4 до 48 років на час операції, спостерігалося чітке зростання частоти оксифільноклітинної метаплазії зі збільшенням віку хворих.

Порівняння ПТК із наявними та відсутніми оксифільними змінами виявило, що в наймолодшій віковій групі (діти до 14 років на момент операції, в яких частота таких змін була найнижчою) оксифілію пов’язано переважно 3 клітинами солідних осередків за дифузносклерозуючого гістологічного варіанта ПТК і більшою дозою опромінення ЩЗ. У старших вікових групах (29-38 і 39-48 р. на момент операції), в яких частота оксифільноклітинної метаплазії перевищувала 50\% як у первинних пухлинах, так і в первинних метастазах, простежувалася асоціація таких змін із трабекулярно-солідною домінуючою будовою пухлини. Незважаючи на вкрай сприятливий перебіг ПТК, поодинокі рецидиви регіонарного метастазування виникали саме у хворих із визначеними оксифільноклітинними змінами.

Отже, виконані дослідження встановили, що наявність оксифільноклітинної метаплазї в первинних пухлинах і первинних метастазах може певною мірою розглядатися як прогностичний чинник виникнення рецидивів регіонарних метастазів, які потребують повторного оперативного втручання.

НДР «Визначити особливості змін системи імунітету у хворих на токсичний зоб і карциному щитоподібної залози за умов лікування радіойодом» (наукові керівники: д.мед.н., професор, акад. НАМН України, член-кор. НАН України Тронько М.Д., к.б.н. Замотаєва Г.А.)

Імунологічний моніторинг хворих на токсичний зоб і РЩЗ у процесі лікування радіойодом показав, що у хворих на токсичний зоб ще перед лікуванням радіойодом були значні порушення в імунній системі, характерні для автоімунного процесу. Попри значну різницю в активності радіойоду, яку застосовували для лікування хворих на РЩЗ і дифузний токсич- ний зоб (3,7-7,4 ГБк і 0,4-0,8 ГБк відповідно), основні тренди змін імуногематологічних показників були схожими. Водночас ступінь порушень у системі імунітету та терміни відновлення у хворих на токсичний зоб були меншими. Проаналізовано дані залежно від дози радіойоду, його розподілу в організмі та вихідного стану імунної системи хворих. Визначено основні чинники, що впливають на характер і ступінь імунних порушень після РЙТ.

Також протягом 2018 р. в Інституті продовжували виконувати ще 5 перехідних НДР, що фінансуються з бюджету НАМН України за КПКВ 6561040 «Прикладні та науковотехнічні розробки», із термінами виконання 2017-2019 рр.:

«Розробка індивідуальних алгоритмів хірургічного лікування пухлин щитоподібної залози, надниркових залоз, первинного та вторинного гіперпаратиреозу» (науковий керівник: д.мед.н., професор Коваленко А.Є.).

«Дослідити окремі механізми патогенезу та фактори ризику розвитку автоімунної офтальмопатії з метою оптимізації їі лікування» (науковий керівник: к.мед.н., с.н.с. Терехова Г.М.).

«Дослідити йодну забезпеченість та участь цинку, заліза та селену в патології щитоподібної залози у жінок у першій половині вагітності» (науковий керівник: д.мед.н., професор Кравченко В.І.).

«Удосконалення методів діагностики папілярних карцином щитоподібної залози та прогнозування розвитку метастатичного процесу для вибору тактики адекватного його лікування» (науковий керівник: д.мед.н., професор Кваченюк А.М.).

«Розробити алгоритм діагностики судинних уражень у хворих із підвищеною масою тіла та ожирінням на тлі порушення вуглеводного обміну» (науковий керівник: к.мед.н., с.н.с. Орленко В.Л.).

МІЖНАРОДНІ НАУКОВІ ПРОГРАМИ

Спільний Українсько-Американський «Науковий проект дослідження раку та інших захворювань щитоподібної залози в Україні в результаті аварії на Чорнобильській AEC》 (науковий керівник: д.мед.н., професор, акад. НАМН України, член-кор. НАН України Тронько М.Д.; співвиконавець і джерело фінансування - Національний інститут раку (CIIA)). 
Українсько-Американський тиреоїдний проект виконується в рамках міждержавної Угоди від 08.12.1999 р. між Кабінетом Міністрів України та Урядом США про співробітництво в галузі досліджень із проблем впливу аварії на Чорнобильській AEC на довкілля та здоров'я людей.

Упродовж 2018 р. обстежено 980 членів когорти з вузловою патологією ЩЗ, виявлено 7 випадків папілярних карцином, 1 випадок фолікулярної аденоми та 4 випадки багатовузлового зоба, проанкетовано 1957 членів когорти та ідентифіковано 3450 матерів, які годували немовлят груддю під час аварії на ЧАЕС.

ГРАНТИ МІЖНАРОДНИХ ОРГАНІЗАЦІЙ

Міжнародний проект СП5-Свроатом № 211712 «Чорнобильський банк тканин координовані міжнародні дослідження радіоіндукованого тиреоїдного раку» (наукові керівники: д.мед.н., професор, акад. НАМН України, член-кор. НАН України Тронько М.Д., д.б.н., професор Богданова Т.І.; співвиконавці та джерела фінансування Національний інститут раку (США), Європейський Союз, Фонд «Сасакава» (Японія))

У рамках проекту зібрано парафінові блоки 167 випадків доброякісних і злоякісних пухлин Щ3. 149 пацієнтів погодилися здати кров. Усю інформацію щодо зібраних випадків внесено до бази даних Чорнобильського банку тканин (ЧБТ), а гістологічні препарати (парафінові та заморожені зрізи, забарвлені гематоксилін-еозіном) передано до Координаційного центру проекту для їх сканування та надання наступній, 25-й Патологічній панелі.

Також розроблено макети електронних таблиць щодо передопераційного (гормональний статус, цитологічні висновки ТАПБ ЩЗ за TBSRTC-класифікацією, дані ультразвукової діагностики) та поопераційного (тривалість спостереження, гормональний статус, дані ультразвукової діагностики, повторні операції, для тиреоїдних карцином - TNM статус за 7-ю та 8-ю класифікаціями TNM, результати радіойодтерапії або променевої терапії, наявність додаткових раків, дата та причина можливої смерті) спостереження хворих.

Створено алгоритм і програму, яка виконує автоматичний аналіз численних текстових і цифрових даних клінічної бази Інституту та формує електронні таблиці згідно з погодже- ним переліком колонок і зразків відповідей, наведених у примітках заголовків колонок. Інтерфейс програми розроблено таким чином, аби за допомогою інтерактивних налаштувань стало можливим отримувати дані за різні періоди існування ЧБТ і за довільними списками ЧБT ID. За його допомогою здійснено передачу даних до Координаційного Центру ЧБТ стосовно 579 хворих (членів когорти ЧБТ), яких було прооперовано 1998-1999 і 2016-2018 роками.

\section{СПІВРОБІТНИЦТВО З НАУКОВИМИ УСТАНОВАМИ}

Упродовж 2018 р. у рамках співробітництва 3 науковими установами заплановано проведення клінічного дослідження з вивчення безпеки застосування автологічних клітин стромально-васкулярної фракції жирової тканини для лікування критичної ішемії кінцівок - із Центром регенеративної медицини Університету Флориди, США. Виконувалися епідеміологічні аналітичні дослідження даних із реєстру хворих на ЦД - із ДУ «Інститут геронтології імені Д.Ф. Чеботарьова НАМН України», Колумбійським університетом (Нью-Йорк, США), Медичним центром Лейденського університету (Лейден, Нідерланди).

Також досліджували:

- вплив нітратів на потенціювання радіогенного раку ЩЗ - із ДУ «Інститут громадського здоров’я ім. О.М. Марзеєва НАМН України» і Національним науковим центром радіаційної медицини НАМН України;

- активність кінази S6 у 50 відібраних зразках аденом і карцином Щ3 - з Інститутом молекулярної біології і генетики НАН України;

- визначали довжини теломер лейкоцитів периферичної крові хворих на ЦД та осіб із порушеною регуляцією рівнів глюкози - iз ДУ «Інститут геронтології ім. Д.Ф. Чеботарьова НАМН України»;

- безпечність трансплантації мікроінкапсульованих тканин ендокринних залоз із ДУ «Інститут медицини праці НАМН України»;

- йодну забезпеченість та участь цинку, заліза та селену в патології ЩЗ у жінок у першій половині вагітності - із ДУ «Національний медичний університет ім. О.О. Богомольця»; 
- провідні чинники ризику, механізми розвитку та особливості перебігу серцево-судинної патології у хворих на ЦД - із ДУ «Інститут серцево-судинної хірургії ім. М.М. Амосова НАМН України».

Розробляли:

- техніку виконання андреналектомій лапароскопічним i ретроперитонеальним ендоскопічними міні-інвазійними доступами - із ДУ «Національний інститут хірургії та трансплантології імені О.О. Шалімова НАМН України»;

- алгоритм діагностики судинних уражень у хворих із підвищеною масою тіла та ожирінням на тлі порушення вуглеводного обміну - із ДУ «Інститут ядерної медицини та променевої діагностики НАМН України».

Проведено молекулярно-генетичні дослідження з метою ранньої діагностики синдрому біологічно неактивного гормону росту з Інститутом фізіології імені О.О. Богомольця НАН України.

УЧАСТЬ У МІЖНАРОДНИХ НАУКОВИХ ОРГАНІЗАЦІЯХ

Наукові співробітники Інституту є членами і беруть участь у роботі міжнародних наукових організацій і комітетів: Експертної групи проекту «Моніторинг щитоподібної залози після ядерних аварій (TM-NUC)» -1 , Свропейської асоціації ендокринологів - 14, Європейської асоціації з вивчення цукрового діабету - 8, Європейської тиреоїдної асоціації - 2, Нью-Йоркської академії наук - 3, Європейської асоціації гематологів - 1, Міжнародної федерації нейроендокринологів - 1, Болгарської асоціації андрологів - 1, Американської діабетичної асоціації - 2, Інтернаціональної академії патології - 1, Свропейської групи з надання первинної допомоги хворим на цукровий діабет - 1, Свропейського співтовариства хірургів-ендокринологів -1 .

\section{ІННОВАЦІї}

\section{Патенти}

Упродовж 2018 року отримано охоронні документи на об’єкти права інтелектуальної власності - 6 патентів на корисні моделі:

- патент 730649 Україна, МПК А61В 8/13 (2006.01). Спосіб визначення термінів клінічного дебюту ЦД 1-го типу в дітей і підлітків. № u201802576, заявл. 14.03.2018 р., опубл. 26.12.2018, бюл. № 25;
- патент 124677 Україна, МПК А61В 8/13 (2006.01). Спосіб диференційної діагностики пухлин щитоподібної та прищитоподібних залоз. № u201706255; заявл. 19.06.2017 р., опубл. 25.04.2018, бюл. № 8;

- патент 129035 Україна, МПК А61В 5/00 G01N33/48 (2006.01). Спосіб визначення ефективності дії цукрознижувальних препаратів. № u201711658; заявл. 29.11.2017 р., опубл. 25.10.2018, бюл. № 20;

- патент 129213 Україна, МПК G01N33/50 (2006.01). Спосіб контролю ефективності зниження маси тіла дітей і підлітків з ожирінням на тлі дисфункції гіпоталамуса. № u201804205; заявл. 17.04.2018 р., опубл. 25.10.2018, бюл. № 20;

- патент 129920 Україна, МПК А61В 17/00 (2018.01). Спосіб малоінвазійного хірургічного втручання при захворюваннях щитоподібної залози. № u201802300; заявл. 05.03.2018 р., опубл. 26.11.2018, бюл. № 22;

- патент № 124665 Україна, МПК А61К 31/726, А61/Р 3/10 (2006.01). Спосіб лікування діабетичних артропатій у хворих із підвищеною масою тіла. № u201613597; заявл. 29.12.2016 р., опубл. 25.04.2018, бюл. № 8.

\section{Нові технологіi}

У ході виконання НДР створено 3 нові технології:

- спосіб визначення агресивності пухлин щитоподібної залози людини за інтенсивністю експресії мРНК RET-PTC1 i RETPTC3 (державний реєстраційний номер 0619U000025);

- спосіб визначення ефективності ліпідокоригуючої терапії у хворих на цукровий діабет 2-го типу з ізольованими дисліпідеміями (державний реєстраційний номер 0619U000026);

- спосіб визначення ефективності дії цукрознижувальних препаратів (державний реєстраційний номер 0619U000024).

\section{Нововведення}

За результатами завершених НДР 2018 року запропоновано 12 нововведень, які впроваджено в практику (із них 10 нововведень стосуються методів діагностики, 2 нововведення методів лікування ендокринних захворювань та їх ускладнень):

- Інтраопераційні експрес-гістологічні дослідження та сучасні зміни в патологічній діа- 
Актуальна інформація

гностиці пухлин щитоподібної залози.

- Зміни в патологічній діагностиці пухлин щитоподібної залози після впровадження в практику 4-го видання Гістологічної класифікації пухлин ендокринних органів BOО3 і 8-го видання класифікації TNM, які можуть впливати на тактику хірургічного лікування.

- Досягнення компенсації цукрового діабету в дітей і підлітків із використанням сучасних неінвазійних безпровідних глюкометрів.

- Методика диференційної діагностики синдрому біологічно неактивного гормону росту, рецепторної нечутливості до гормону росту та ідіопатичної низькорослості.

- Визначення 1,5-ангідроглюцитолу в крові хворих дітей і підлітків для оцінки компенсації цукрового діабету 1-го типу.

- Діагностика порушень функціонального стану гіпофізарно-гонадної системи та патоспермії в чоловіків, хворих на рак щитоподібної залози, після комбінованого лікування.

- Прогнозування розвитку серцевої недостатності у хворих на цукровий діабет 2-го типу за допомогою визначення натрійуретичного пептиду.

- Вивчення ефективності цукрознижувальної терапії у хворих на цукровий діабет 2-го типу.

- Діагностичні критерії ураження серцевосудинної системи у хворих на цукровий діабет 1-го типу.

- Спосіб оцінки ризику наявності цукрового діабету.

- Спосіб виявлення погіршення якості кісткової тканини внаслідок уповільнення синтезу білкового матриксу у хворих на цукровий діабет 2-го типу шляхом визначення рівня остеокальцину.

- Спосіб використання доплерографічних показників ниркової гемодинаміки як прогностичний маркер формування нефропатії залежно від фенотипових особливостей.

Наступного року запропоновано до «Інформаційного бюлетеня НАМН України» 4 нововведення:

- Спосіб визначення ефективності дії цукрознижувальних препаратів.

- Спосіб визначення показників обміну сечової кислоти в пацієнтів, хворих на цукровий діабет 2-го типу, з різними фенотиповими особливостями на тлі лікування інгібіторами натрій-глюкозного котранспортера 2 (SGLT-2).

- Спосіб виявлення порушень сперматогенезу в чоловіків, хворих на рак щитоподібної залози, після комбінованого лікування.

- Спосіб контролю ефективності зниження маси тіла дітей і підлітків з ожирінням на тлі дисфункції гіпоталамуса.

Впровадження всіх нововведень підтверджено 23 актами.

\section{Видання}

2018 року видано монографію «Молекулярные механизмы патогенеза сахарного диабета и его осложнений» (Тронько Н.Д. та ін.), Державний формуляр лікарських засобів, випуск 10 «ндокринологія. Лікарські засоби. Розділ 7» (Тронько М.Д. та ін.), методичні рекомендації «Поради пацієнтам із цукровим діабетом», а також 4 інформаційні листи:

- Методика диференційної діагностики синдрому біологічно неактивного гормону росту, рецепторної нечутливості до гормону росту та ідіопатичної низькорослості.

- Визначення 1,5-ангідроглюцитолу в крові хворих дітей і підлітків для оцінки компенсації цукрового діабету 1-го типу.

- Схема призначення препаратів селену під час лікування хвороби Грейвса з автоімунною офтальмопатією.

- Застосування методів передопераційного прогнозування радіойодрезистентності папілярних карцином щитоподібної залози для визначення ефективності радіойодтерапії та тактики лікування.

Видано 4 номери журналу «Ендокринологія/Endokrynologia», який внесено до міжнародної наукометричної бази Index Copernicus Journal Master List і бази даних повнотекстових наукових журналів Open Academic Journal Index, i 1 додаток до нього.

Наукові співробітники Інституту опублікували 169 праць, у т. ч. 15 - за кордоном. До них входять: 1 колективна монографія, 1 методичні рекомендації, 4 інформаційні листи, 101 стаття в періодичних наукових журналах і збірниках (із них 11 - за кордоном), 61 теза в наукових збірниках (із них 4 - за кордоном), 19 статей опубліковано у виданнях, що індексуються наукометричними базами Web of Sciene та/або Scopus. Окрім цього, співро- 
бітники Інституту оформили 4 автореферати дисертацій.

Троє науковців Інституту є членами редколегій іноземних періодичних видань, що входять до наукометричних баз Scopus/Web of Science.

\section{Вчена рада}

Відповідно до п. 6 Типового Положення про вчену раду науково-дослідної установи НАМН України, затвердженого Постановою Бюро Президії НАМН України № 25/3 від 22 грудня 2017 року, обрано новий склад вченої ради в кількості 24 осіб, затверджений Постановою Президії НАМН України 12 квітня 2018 року № 7/6. Серед членів вченої ради 2 академіки НАМН України та член-кореспонденти НАН України, 14 докторів і 8 кандидатів наук. Очолює вчену раду директор Інституту, д.мед.н., професор, акад. НАМН України, член-кор. НАН України Тронько М.Д.

2018 року відбулося 7 засідань вченої ради, на яких розглянуто 79 питань. Серед них 80\% стосувалися наукової, 4\% - організаційно-методичної, 4\% - лікувальної та 2\% - господарчої діяльності установи.

\section{Спеціалізована вчена рада}

Наказом МОН України № 374 від 13.03.2017 р. утворено спеціалізовану вчену раду Д 26.558.01 із правом прийняття до розгляду та проведення захисту дисертацій на здобуття наукового ступеня доктора (кандидата) терміном на 3 роки за фахом 14.01.14 - «ендокринологія» (медичні та біологічні науки).

Протягом 2018 року на засіданнях спеціалізованої вченої ради зі спеціальності «ендокринологія» захищено шість кандидатських дисертацій: 3 - медичні науки, 3 - біологічні науки.

\section{Підготовка кадрів}

Рішенням Атестаційної колегії Міністерства освіти і науки України від 02.11.1999 р., протокол № 4/9-2/4, затверджено постійно діючу докторантуру зі спеціальності 14.01.14 - «ендокринологія» в Інституті, яку перереєстровано рішенням Атестаційної колегії Міністерства освіти і науки України від 27.12.2002 р., протокол № 759.

В Інституті постійно здійснюється робота, спрямована на підготовку кадрів вищої кваліфікації - кандидатів і докторів наук, через аспірантуру зі спеціальності 14.01.14 - «ен- докринологія» та підготовку дисертацій здобувачами. Наприкінці 2018 р. на базі Інституту здобувачами виконувалися 8 докторських i 6 кандидатських дисертацій.

Відповідно до рішення Атестаційної колегї Міністерства освіти і науки України від 05.07.2018 р. присвоєно вчене звання професора зі спеціальності 222 «Медицина» доктору медичних наук Кваченюку А.M.

Відповідно до пункту 1 частини другої статті 6 Закону України «Про ліцензування видів господарської діяльності» та на підставі рішень Ліцензійної комісії Міністерства освіти і науки України (протокол № 56/2 від 15.06.2017 р.) Інституту видано ліцензію на впровадження освітньої діяльності у сфері вищої освіти: підготовка докторів філософії на третьому (освітньо-науковому) рівні вищої освіти в галузі знань 22 «Охорона здоров'я» за спеціальністю 222 «Медицина» (спеціалізація «ендокринологія») із ліцензійним обсягом освітньої послуги - 10 осіб. (Підстава: Наказ МОН України № 123-л від 16.06.2017 р.).

Станом на 01.01.2018 р. в аспірантурі зі спеціальності 14.01.14 - «ендокринологія» навчалися два аспіранти, усі в аспірантурі без відриву від виробництва. Завершили навчання в аспірантурі дві особи.

Із метою підвищення фахової кваліфікації лікарів-ендокринологів України проведено 3 науково-практичні конференції з питань сучасної теоретичної та клінічної ендокринології: «Школа ендокринолога для сімейних лікарів (освітній проект)» (Черкаси, 30.03.2018 р.), «Сучасні проблеми 3 навчання хворих на цукровий діабет самоконтролю» (Миргород, 1415.06.2018р.), «Сучасні аспекти діагностики та лікування ендокринної патології в дітей і підлітків» (Київ, 17.10.2018 р.). У роботі цих конференцій взяли участь понад 470 ендокринологів.

Із 1992 р. на базі Інституту організовано кафедру ендокринології Національної медичної академії післядипломної освіти ім. П.Л. Шупика МОЗ України. 2018 року проведено 10 циклів: ПАЦ за фахом «Дитяча ендокринологія», ТУ «Гінекологічна ендокринологія», ПАЦ за фахом «Ендокринологія», ТУ «Вибрані питання клінічної ендокринології», ТУ «Ендокринні аспекти патології статевих залоз», спеціалізація за фахом «Ендокриноло- 
гія» та спеціалізація за фахом «Дитяча ендокринологія».

Також проведено додатково позапланові виїзні та індивідуальні цикли підвищення кваліфікації лікарів-ендокринологів: два виїзні цикли ТУ «Вибрані питання клінічної ендокринології» (31 лікар), 7 індивідуальних циклів стажування за фахом «Ендокринологія», 2 цикли спеціалізації за фахом «Дитяча ендокринологія», а також 2 індивідуальних цикли за фахом «Ендокринологія».

Усього протягом 2018 р. на планових циклах підвищили кваліфікацію 204 лікарі: 31 - на додаткових, у тому числі 18 лікарів-педіатрів.

У клінічних підрозділах і лабораторіях Інституту існують профільні курси інформації та стажування лікарів на робочих місцях. Протягом року підготовлено 17 лікарів різних фахів (педіатри, лікарі функціональної діагностики, хірурги, цитологи) з усіх регіонів України.

\section{Лікувально-профілактична робота}

Лікарський штат клініки Інституту складається з 58 осіб (із них 1 - д.мед.н., 9 - к.мед.н., 36 осіб мають вищу категорію, 3 - першу та 7 - другу).

Ліжковий фонд клініки складається із 196 ліжок і розподіляється по відділеннях: дитячої ендокринної патології - 30 ліжок, діабетології - 40, загальної ендокринної патології - 40, хірургії ендокринних залоз із реанімацією - 40, радіологічне - 10, офтальмо-ендокринної патології - 8, клінічної фармакологіï - 14, денний стаціонар - 14 ліжок.

Аналіз ефективності роботи клініки Інституту свідчить, що планові показники її роботи істотно не відрізняються від показників інших клінік: проліковано хворих у стаціонарі 5 191, проведено ліжко-днів - 56016 , середне число зайнятості ліжок - 285,8, середній обіг ліжка - 26,48, середня тривалість перебування хворого на ліжку - 10,79 дня, виконання плану ліжко-днів - 96,4\%, що є оптимальним на даному етапі.
У стаціонарі проліковано 1\% хворих I категорії складності, 3\% - II, 43\% - III, 28\% - IV і 25\% V категорії складності, тобто в клініку Інституту госпіталізують хворих зі складною ендокринною патологією. Летальність - 0,0\%. За звітний період госпіталізовано тематичних хворих 75,4\%.

У консультативній поліклініці Інституту прийнято 43863 хворих, у т.ч. 40100 дорослих i 3762 дитини, 19854 киянина і 7800 мешканців сільської місцевості.

Головною акредитаційною комісією при МОЗ України 2018 року клініці Інституту присвоєно вищу категорію.

\section{Штат співробітників}

Станом на 01.01.2019 р. в Інституті працюють 459 співробітників, у т.ч. за розділом «клініка» - 338 (58 лікарів, 1 доктор наук і 9 кандидатів наук) і за розділом «наука» 121 (77 наукових співробітників, 19 докторів наук і 39 кандидатів наук).

У складі вчених Інституту працюють: академік НАМН України і член-кореспондент НАН України Тронько М.Д.; академік НАМН України і член-кореспондент НАН України Резніков О.Г., а також 11 професорів, 8 заслужених діячів науки і техніки України і 3 заслужених лікарі України. Провідні вчені Інституту є членами та експертами міжнародних організацій - ООН, ВОО3, членами іноземних академій наук і наукових товариств.

2018 року отримали державні нагороди: Резніков О.Г. - Орден «За заслуги» III ступеня, Богданова T.I. - почесне звання «Заслужений діяч науки і техніки України», Ковзун O.I. - Грамоту Верховної Ради України «За заслуги перед Українським народом».

Також минулого року присуджено Нагасакську Меморіальну премію миру ім. Такаші Нагаї доктору біологічних наук, професору, заслуженому діячу науки і техніки України Богдановій T.I. за особистий вагомий внесок у вдосконалення медичної допомоги постраждалим від радіаційого впливу. 